\title{
Motherhood Choices of women attending Antenatal Care in a Tertiary Level Hospital in the Niger Delta Region of Nigeria
}

\author{
*Dr Emmanuel Columba Inyang-Etoh. (Fmcog, Fwacs), Dr Aniefiok Jackson \\ Umoiyoho. (Fwacs, Fics) \\ ${ }^{1}$ Senior lecturer/Consultant, Dept. of Obstetrics and Gynecology, University of Uyo, Nigeria. \\ ${ }^{2}$ Associate Professor/Consultant, Dept. of Obstetrics and Gynecology, University of Uyo, Nigeria. E-MAIL=
}

\begin{abstract}
Introduction: Human reproduction is the primary responsibility of women, so the choices they make in this regard will continue to shape obstetric practice in different parts of world.

Methods: During the 2months period of the study of women attending antenatal care in the study centre, pretested, structured partly pre-coded questionnaires were used to sample a cross section of suitable consenting women's motherhood preferences and the reasons for such choices.

Results: Out of the 452 women in the study population, $96.7 \%$ preferred to deliver vaginally, positing that it was the natural route of delivery. A mere $14.4 \%$ of the respondents would demand labour anaesthesia, while the majority (67.6\%) were not sure they would demand labour analgesia. Eighty-nine (20.3\%) of the mothers would not accept a medically indicated caesarean section even as the only safe option for delivery, and 10 (2.3\%) would not mind if their babies died in the course of such refusal. Among those who would refuse caesarean section, a vast majority (66.3\%) felt it was against God's plan for human procreation. Age, parity and booking status of the women did not influence their refusal of caesarean section, whereas women with lower levels of education $(p=0.033)$ and those who engaged in less skilled occupations were more likely to decline medically indicated caesarean section $(p=0.000)$. Over half $(55.0 \%)$ of the mothers preferred to have 4 children, while only $24.7 \%$ of the women felt 3 or less children were appropriate. Conclusion: Nigeria is a pronatalistic society where the majority of mothers prefer to deliver 4 or more children. Due to cultural and religious misconceptions, some Nigerian women decline medically indicated caesarean section with adverse maternal and perinatal consequences. The need for continued effort toward the education of the girl-child and public enlightenment on the need for Nigerians to embrace time tested maternity care interventions have become imperative.
\end{abstract}

Keywords: Caesarean section, Children, delivery, motherhood, Nigeria, preferences, reasons, refusal.

\section{Introduction}

Motherhood, which has been defined as a state of being a mother is a phenomenon that is not unique to humans[1]. Motherhood is common to the entire animal kingdom and is driven by primitive instincts and the need for perpetuation of each animal species.

Human procreation started after God created the first man and woman, Adam and Eve when He mandated them:

"Be fruitful and multiply and replenish the earth, and subdue it ..."[2] Even in biblical times, childbirth was not without its challenges, as the Bible records the first maternal mortality, when Rachel, the second wife of Jacob died of so called "hard labour" after delivering her second son, Benjamin[2].

In the ancient world, childbirth was imperative to the family for various traditional and cultural reasons, but it was also shrouded in mythology and superstition[3]. At that time, success at childbirth was seen as a favour from the gods, while the frequent maternal deaths that occurred were attributed to fate[3,4].

It was after the first successful caesarean section (c-section) was performed in Switzerland in 1500 by Jacob Nufer, the desperate husband of a woman who had been in labour for several days under the supervision of 13 midwives to no avail, that childbirth became more predictable due to this discovery of an alternative route of delivery[5].Vaginal delivery remains the natural route of childbirth; although, there are situations when this route might be unsafe for either the mother and or the infant[6,7]. In such situations, caesarean section provides an alternative route of delivery, which has been proven to be safe for both the mother and her infant[7]. Even though caesarean section has a higher risk of maternal morbidity and mortality when compared to vaginal delivery, this risk has been reduced to the barest minimum due to the evolution of safe surgical technique, safe and effective anaesthesia, as well as potent antibiotics and safe blood transfusion[8,9,10].

Notwithstanding the undeniable role of caesarean section in successful childbirth and the safety of the procedure in modern times, Nigerian women have developed aversion to caesarean section for various cultural 
and religious reasons[11,12]. Such aversion often result in these women refusing caesarean section when medically indicated, with negative consequences to them and their infants[13,14].

An invariable complication of unjustified attempt or persistence on vaginal delivery with or without a caesarean section scar is uterine rupture, which has made significant contribution to maternal and perinatal mortality in the tropics[14,15]. This occurs against the backdrop that as many as $63 \%$ of births by Nigerian women occur in private or traditional attendant homes by the choice of such mothers[16]. In contrast, in developed countries of the world, virtually all childbirths take place in well-equipped and well-staffed health facilities, and the role of caesarean section in successful childbirth is well appreciated by the populace[8].

In the University of Uyo Teaching Hospital Maternity Unit, a referral centre for a population of over 5million people[16], some mothers decline caesarean section even after they have been duly counselled on the necessity of the intervention, with adverse perinatal consequences. This study was designed to sample the opinion of mothers about their preferred mode of delivery, the reasons for their preferences, and other related motherhood choices. It is envisaged that the findings of this study would help us understand why Nigerian women make certain choices regarding motherhood.

\section{Study design and study area}

\section{Methodology}

This was a questionnaire- based descriptive study of mothers who attended antenatal visits during a two month period from $1^{\text {st }}$ October to $30^{\text {th }}$ November 2015 in the Maternity unit of the University of Uyo Teaching Hospital, Uyo, Nigeria.

The University of Uyo Teaching hospital is the only tertiary level health care facility in Akwa Ibom State, located in the south-south geopolitical zone of Nigeria. The state has a population of 3.9million people according to the Nigerian census conducted in 2006 and projected to 5.1million people by 2015[16]. Akwa Ibom state is one of the 36 states of the federal republic of Nigeria, and it has one federal university teaching hospital, one state owned newly established quaternary hospital, 3 academic institutional medical centres, 16 general hospitals and 125 private clinics[17].

Uyo is the capital of Akwa Ibom State, which has 31 local government areas. The people of the state are predominantly government employed civil servants, and other people indulging in peasant farming, fishing, petty trading as well as small and medium scale businesses[16].

\section{Data collection and analysis}

Approval was obtained from the University of Uyo Teaching Hospital Health Research Ethical Committee before commencement of the study. Selected Resident doctors in the department were trained to serve as research assistants and to administer the questionnaires to women attending antenatal visits in the centre during the study period. The mothers were counselled on the purpose of the study and informed that participation in the study was voluntary. The freedom of the women to withdraw from the study at any time should they desire to do so was emphasized to them. Women who declined to participate in the study, those who were found to be emotionally unstable and anyone who had a mental illness were excluded from the study. Each eligible mother was sampled only once. The calculated minimum sample size was 205.

The questionnaire, which was structured and partly pre-coded had been pretested among a cross section of 20 women attending antenatal care in a peripheral general hospital in the state 3 months earlier and necessary corrections made to improve the validity and reliability of the questions.

The questionnaires were administered by research assistants to a cross section of suitable consenting women attending antenatal care on every clinic day for the period of the study for self-completion. Respondents who were not literate were assisted through interpretation to complete the forms, and those who needed explanations, members of the research team attended to them. The first part of the questionnaire was designed to obtain demographic and obstetric parameters of the respondents. The second part of the questionnaire was made up of 9 items, which focused on preferred mode of delivery by the mothers, whether they would accept caesarean section if that was the only safe option for delivery, the number of children they prefer to have and the reasons for their preferences. For example, respondents were asked: How do you prefer to be delivered? Caesarean section or Vaginal delivery; an open ended question was then asked, what is the reason for your choice? For those who preferred vaginal delivery, two further questions were asked: Would you demand anaesthesia to control labour pain? Yes, no, not sure. Would you accept caesarean section if that is the only safe option for your delivery? Yes or no? For those who responded No, an open ended question was then asked, what is your reason for not accepting caesarean section? Respondents were also asked: What number of children would you prefer to have? Options one to ten were given. The reason for preferred number of children was then asked for them to provide their individual reasons.

Data generated from the study were coded and entered into the software of the Statistical Package for Social Sciences (SPSS), Version 17 Inc. Chicago, Illinois, USA. Descriptive statistics were performed for 
continuous variables and deductions were made using descriptive and inferential statistics. Association between selected respondents' parameters and preferred mode of delivery as well as refusal to accept caesarean section as the only safe option were computed using the Fisher's Exact test and differences were considered significant at a p-value of less than 0.05 .

\section{Results}

Out of 570 mothers who attended antenatal care at least once during the two months period of the study, 453 women were recruited into the study, which constituted the study population with the age range of 17 -43 years and a mean age of $29.07 \pm 4.70$ years. Their mean height was $1.61 \pm 0.06 \mathrm{~m}$ and mean weight of 78.61 $\pm 16.01 \mathrm{~kg}$. Most $(98.9 \%)$ of the respondents were Christians, while the remaining $1.1 \%$ were Muslims. Table 1 shows the demographic and obstetric parameters of the respondents. The vast majority $428(94.5 \%)$ of the women were married, $289(63.8 \%)$ had attained post-secondary level of education and $404(89.2 \%)$ were booked attending antenatal care in the centre. The mode of delivery preferred by women, reasons for such preferences and other related issues are shown in table 2. Most, (96.7\%) of the mothers preferred to deliver vaginally with the majority $285(65.1 \%)$ adducing the fact that it was a natural process as their reason. Among the $96.7 \%$ who preferred vaginal delivery, $296(67.6 \%)$ were not sure they would demand for anaesthesia during labour, while $79(18.0 \%)$ stated they would not demand anaesthesia. Eighty-nine (20.3\%) would not accept caesarean section, even though it is the only safe option for delivery. Table 3 shows that parity, booking status, level of education and occupation of the respondents did not influence significantly their preferred mode of delivery. However, women 30 years and younger were more likely to prefer vaginal delivery. Table 4 shows the reasons mothers would refuse caesarean section and the number of children they prefer to have. The majority 59 $(66.3 \%)$ of the mothers would refuse caesarean section because they feel it is against God's plan for procreation, while $10(2.3 \%)$ of those who declined caesarean section would not mind if their baby should die in the process. More than half of the respondents, 249 (55.0\%) preferred to have 4 children and the majority $259(57.2 \%)$ of the respondents felt a small family of 4 or less was preferable. Respondents with lower levels of education were significantly more likely to refuse caesarean section even though it was the only safe option for delivery, the same with respondents who engaged in less skilled labour, which was highly statistically significant. The age, gestational age, parity and booking status of the women did not influence their decision to decline caesarean section even as the only safe option for delivery.

\section{Discussion}

Since women bear the primary responsibility of human reproduction, the choices they make in this regard will continue to shape the practice of obstetrics either in developing countries of Africa and parts of Asia or in industrialized nations of the West. Insight into the reasons women in Africa make certain motherhood choices as opposed to their counterparts in industrialized nations of Europe and America is of interest to the socially inquisitive obstetric mind.

The study population was made up of largely young, married, educated, Christian pregnant women, who were receiving antenatal care in the centre; this is a typical socio-demographic profile of obstetric populations in southern Nigeria. As would be expected, most $(96.7 \%)$ of the mothers preferred to deliver vaginally for various reasons; interestingly, the majority $(65.1 \%)$ of the women correctly posited that it is the natural process of childbirth[6,7].

Among the mothers who preferred vaginal delivery, 296 (67.6\%) were not sure they would demand analgesia or anaesthesia to control labour pain, even though labour pain has been described by some authorities as extremely painful[18,19]. Nevertheless, pain perception is subject to individual variations[19]. The large proportion of mothers not being sure whether they would demand labour analgesia might not be unrelated to the fact that many mothers in Africa are not even aware of the availability of such pain relief during child birth, unlike what is obtained in industrialized nations of the world[18,19,20]. A study in Uganda revealed that only $7 \%$ of women in that series had knowledge of obstetric anaesthesia, which mirrors the results of this study, where only $14.4 \%$ of mothers would demand obstetric anaesthesia[19]. This is contrary to what was obtained in Alabama, USA, where $50 \%$ of mothers actually demand and receive obstetric anaesthesia during labour[20].

Among the mothers who opted for vaginal delivery, as many as $20.3 \%$ of them would refuse caesarean section even when medically indicated, in confirmation of the aversion African women have to caesarean section[11,12]. Such aversion often result in uterine rupture as well as maternal and perinatal morbidity and mortality[13,14,15]. In contrast, refusal of caesarean section by mothers is unheard of in industrialized countries of the world[8].

Not surprisingly, the few (3.7\%) mothers who expressed their preference for caesarean section, did so either for medical reasons or because they had previous caesarean sections and had probably been counselled on the inevitability of a repeat caesarean section in subsequent deliveries. 
While mothers older than 30 years opted for caesarean section apparently for medical reasons $(\mathrm{p}=$ 0.012), the booking status of the women, level of education and occupation of mothers in the study population did not have any significant influence on the mode of delivery preferred by them $(\mathrm{p}>0.05)$. The reasons mothers would refuse caesarean section as the only safe option for delivery was more revealing. The majority $(66.3 \%)$ of the mothers posited that it was against God's plan for procreation, apparently, because most $(98.9 \%)$ of the respondents were Christians, and anecdotal evidence in Uyo has revealed that Nigerian women often express their desire to deliver as the Hebrew women, who were described by Egyptian midwives according to the Holy Bible thus: "Because the Hebrew women are not as the Egyptian women; for they are lively, and are delivered before the midwives come in unto them". [2] This finding has confirmed the suspicion that some inappropriate motherhood choices that Nigerian mothers make emanate from superstition and misconceived cultural and religious beliefs[11,12]. Tenacious adherence to such misconceptions probably explains why $2.3 \%$ of the mothers in the study population would not mind their babies dying rather than accept a medically indicated caesarean section.

Over half $(55.0 \%)$ of the mothers opted for 4 children, while $20.3 \%$ preferred more than 4 children in agreement with an earlier study in the state[21]. Notwithstanding, when Nigeria is taken as a geopolitical entity with her diverse ethnicity, socioeconomic strata, culture and religion, the total fertility rate is higher, as currently married women desire a large family size of 7.1 and 6.5 for all women[16]. Fifty per cent of Nigerian women consider 6 or more children to be ideal, while only $9 \%$ of women feel 3 or less children is appropriate[16].

Even though, a standardized instrument like the Parenthood-Motivation List developed in the Netherlands was not used in this study to evaluate respondents' motives for motherhood, the reasons adduced by the mothers for their preferred number of children were essentially pronatalistic[22].

Among demographic and obstetric parameters tested for any association with refusal to accept caesarean section as the only safe option for delivery, age, gestational age, parity, and booking status of the women did not have any significant influence on their refusal of caesarean section. Aversion to medically indicated caesarean section was however significantly expressed by mothers with lower levels of education and those who engage in less skilled occupations.

In conclusion, Nigeria is a pronatalistic society with the majority of the mothers desiring to have 4 or more children; sometimes, mothers insist on vaginal delivery due to cultural and religious misconceptions, not minding the adverse consequences of refusing a medically indicated caesarean section. Mothers who were less educated and those who engaged in less skilled occupations were significantly averse to medically indicated caesarean section. Concerted effort by all stake holders to promote girl- child education in Nigeria has become imperative. There is also the need for continuing public enlightenment of the Nigerian populace on the need to embrace available time-tested maternity care interventions in order to reduce maternal and perinatal morbidity and mortality in the country.

\section{Acknowledgement}

We wish to thank the nurses of the antenatal clinic, University of Uyo Teaching Hospital for their assistance during the conduct of the study; also the resident Doctors who served as research assistants and administered the questionnaires to respondents. We are also grateful to Dr Anyiekere Morgan Ekanem who helped us analyse the data.

\section{References}

[1]. Wehmeier S, McIntosh C, Turnbull J. Meaning of motherhood. In: Hornby AS (Ed) Oxford Advanced Learner's Dictionary of current English. $7^{\text {th }}$ Edition. Great Britain: Oxford University Press, 2006; 956-957

[2]. The Holy Bible Reference Edition. Kings James Version. Texas, USA: Jet Move Publishing red Letter Edition, 2008; Genesis 1:2; Genesis 35: 17-19; Exodus 1: 15-19

[3]. Todman D. Child birth in Ancient Rome: from traditional folklore to obstetrics. Australia and New Zealand Journal of Obstetrics and Gynaecology 2007; 47(2): 82-85

[4]. Chamberlain G. Child birth in ancient Egypt. Journal of the Royal Society for the Promotion of Health 2004; 124(6): 284-286

[5]. Warren HP. A brief history of caesarean section. National Library of Medicine in Bethesda, USA. 2013: part 1-4 Available: https://www.nlm.nih.gov/exhibition/caesarean/part1.html Accessed on November 24, 2016

[6]. Cherney K, Kelbach J. History of caesarean section. Health line Media 2005; 19: 32-39 Available: www.healthline.com/health/pregnancy/history-caesarean-section. Accessed on November 24, 2016

[7]. Kwawukume EY. Caesarean section in developing countries. Best Practice Research Clinical Obstetrics and Gynaecology 2001; 1(15): $165-178$

[8]. Ainbinder SW. Caesarean section. In: Decherney AH, Nathan L. (Eds.) Current Obstetrics and gynecologic Diagnosis and Treatment. $9^{\text {th }}$ Edition. USA: McGraw-Hill Company Inc., 2003: 518-528

[9]. Iklaki C. Caesarean section. In: Udoma EJ and Ekanem EI. (Eds.) Textbook of Clinical Obstetrics in the tropics for undergraduate and postgraduate students. ${ }^{\text {st }}$ Edition. Calabar-Nigeria: University of Calabar Press, 2014; 275-282

[10]. Ezechi OC, Fasubaa OB, Kalu BEK, Nwokoro CA, Obiese LO. Caesareans delivery: Why the aversion? Tropical Journal of Obstetrics and Gynaecology 2004; 2(21): 164-167

[11]. Chibu C, Iloabachie G. The burden of caesarean section refusal in a developing country setting. British Journal of Obstetrics and Gynaecology 2007; 10 (114): 1261-1265 
[12]. Adeoye S, Kalu CA. Pregnant Nigerian women's view of caesarean section. Nigerian Journal of Clinical Practice 2011, 14(13): 276-279

[13]. Aziken M, Omo-aghoja L, Okonofua F. Perceptions and attitudes of pregnant women towards caesarean section in urban Nigeria. ACTA Obstetricia et Gynecologica Scandinavica 2010; 1(86): $42-47$

[14]. Eguzo KN, Lawal AK, Ali F, Umezurike CC. Patterns of uterine rupture in Nigeria: a comparative study of scarred and unscarred uterus. International Journal of Reproduction, Contraception, Obstetrics and Gynecology 2015; 4(4): 1094-1099

[15]. Esike COU, Aluka CO, Okali UK, Twomey DE. Contribution of scarred uterus to ruptured uterus in rural Nigeria. International Journal of Reproduction, Contraception, Obstetrics and Gynecology 2016; 5(6): 1790-1795

[16]. National Demographic Health Survey (NDHS) Place of delivery; Projected population of Akwa Ibom state. National Demographic Health Survey $2013 ; \mathbf{1 3 5}-141 ; 18-20$

[17]. Akwa Ibom State Ministry of Health (AKSMOH) Number of health facilities and health personnel in Akwa Ibom state. Updated statistics of Akwa Ibom State for 2015

[18]. Nabukenya MT, Kintu A, Wabule A, Muyingo MT, Kwizera A. Knowledge, attitudes and use of labour analgesia among women at a low-income country antenatal clinic. BioMed Central Anesthesiology 2015; 15: 98-105 DOI: 10.1186/s12871-015-0078-9

[19]. Bilic N, Djakovic I, Klican-Jaic K, Rudman SS, Ivanec Z. Epidural analgesia in labour- controversies. ACTA Clinica Croatica 2015; 3(54): 330-336

[20]. Vincent RD and Chestrut DH. Epidural analgesia during labour. American Family Physician 1998; 58(8): 1785-1792

[21]. Umoh AV, Abah GM, Ekanem US. A study of fertility intentions of women in Uyo, Nigeria. Journal of Public Health and Epidemiology 2012; 1(14): 14-18 DOI: 10.5897/JPHE11.141

[22]. Dyer S, Mokoena N, Maritz J, van der Spuy Z. Motives for parenthood among couples attending level 3 infertility clinic in the public health sector in South Africa. Human Reproduction 2008; 2(23): 352-357 doi: 10.1093/humrep/dem279

Table 1: Demographic and obstetric parameters of mothers in the study population

\begin{tabular}{|c|c|c|}
\hline Parameters & Number (n) & Percentage (\%) \\
\hline \multicolumn{3}{|l|}{ Age in years } \\
\hline$<20$ & 18 & 4.0 \\
\hline $21-25$ & 77 & 17.0 \\
\hline $26-30$ & 202 & 44.6 \\
\hline $31-35$ & 115 & 25.4 \\
\hline $36-40$ & 33 & 7.3 \\
\hline$>40$ & 8 & 1.7 \\
\hline \multicolumn{3}{|l|}{ Parity } \\
\hline P1 & 303 & 66.9 \\
\hline P2-4 & 141 & 31.1 \\
\hline P5-7 & 9 & 2.0 \\
\hline \multicolumn{3}{|l|}{ Marital status } \\
\hline Married & 428 & 94.5 \\
\hline Engaged & 14 & 3.1 \\
\hline Single & 9 & 2.0 \\
\hline Widowed/Divorced & 2 & 0.4 \\
\hline \multicolumn{3}{|l|}{ Educational Level } \\
\hline No formal education & 3 & 0.7 \\
\hline Primary education & 21 & 4.6 \\
\hline Secondary education & 140 & 30.9 \\
\hline Postsecondary & 289 & 63.8 \\
\hline \multicolumn{3}{|l|}{ Occupation } \\
\hline Unemployed & 141 & 31.1 \\
\hline Unskilled & 114 & 25.2 \\
\hline Semiskilled & 56 & 12.4 \\
\hline Skilled/Technical & 127 & 28.0 \\
\hline Professional & 15 & 3.3 \\
\hline \multicolumn{3}{|l|}{ Booking status } \\
\hline Booked & 404 & 89.2 \\
\hline Un-booked & 38 & 8.4 \\
\hline Referred & 11 & 2.4 \\
\hline Total & 453 & 100.0 \\
\hline
\end{tabular}

Table 2: Mode of delivery preferred by mothers and reasons for such preferences

\begin{tabular}{|l|l|l|}
\hline Mode of delivery and reasons & Number (n) & Percentage (\%) \\
\hline Mode of delivery preferred & \multicolumn{2}{|l|}{} \\
Caesarean section & 15 & 3.7 \\
Vaginal delivery & 438 & 96.7 \\
\hline Total & \multicolumn{2}{|c|}{} \\
\hline Reasons for preferring c-section & 7 & 100.0 \\
Previous c-section & 5 & 46.7 \\
Less painful & 3 & 33.3 \\
Medical complications & 15 & 20.0 \\
\hline Total & 285 & 100.0 \\
\hline Reasons for preferring vaginal delivery & \\
It is a natural process & \multicolumn{2}{|l}{} \\
\hline
\end{tabular}




\begin{tabular}{|l|l|l|}
\hline It's God's plan for women & 72 & 16.4 \\
It is convenient & 58 & 13.2 \\
I don't want to undergo surgery & 17 & 3.9 \\
Other reasons & 6 & 1.4 \\
\hline Total & 438 & 100.0 \\
\hline Since you prefer vaginal delivery, would you & & \\
demand anaesthesia for control of labour pain? & & \\
Yes & 63 & 14.4 \\
No & 79 & 18.0 \\
Not sure & 296 & 67.6 \\
& & \\
\hline Would you accept c-section if that is the only & & 79.7 \\
safe option for your delivery? & 349 & 20.3 \\
Yes & 89 & \\
No & $\mathbf{4 3 8}$ & $\mathbf{1 0 0 . 0}$ \\
\hline \multicolumn{2}{|c|}{ Total } & \\
\hline
\end{tabular}

Table 3: Association between selected respondents' parameters and preferred mode of delivery

\begin{tabular}{|c|c|c|c|c|}
\hline \multirow[b]{2}{*}{ Parameters } & \multicolumn{2}{|c|}{ Preferred Mode of Delivery } & \multirow[b]{2}{*}{ Total } & \multirow{2}{*}{$\begin{array}{ll}\begin{array}{l}\text { Statistical } \\
\text { and values }\end{array} & \text { tests } \\
\text { and } & \end{array}$} \\
\hline & Caesarean section & Vaginal delivery & & \\
\hline $\begin{array}{l}\text { Age group (yrs) } \\
<30 \\
>30\end{array}$ & $\begin{array}{l}5(1.7) \\
10(6.4)\end{array}$ & $\begin{array}{l}291(98.3) \\
147(93.6)\end{array}$ & $\begin{array}{l}296 \\
157\end{array}$ & $\begin{array}{l}X^{2}=7.019 \\
D f=1 \\
P=0.012\end{array}$ \\
\hline $\begin{array}{l}\text { Parity } \\
0-4 \\
>5\end{array}$ & $\begin{array}{l}14(3.2) \\
1(11.1)\end{array}$ & $\begin{array}{l}430(96.8) \\
8(88.9)\end{array}$ & $\begin{array}{l}444 \\
9\end{array}$ & $\begin{array}{l}X^{2}=1.745 \\
D f=1 \\
P=0.263\end{array}$ \\
\hline $\begin{array}{l}\text { Booking Status } \\
\text { Booked } \\
\text { Unbooked } \\
\text { Referred }\end{array}$ & $\begin{array}{l}12(3.0) \\
3(7.9) \\
0(0.0)\end{array}$ & $\begin{array}{l}392(97.0) \\
35(92.1) \\
11(100.0)\end{array}$ & $\begin{array}{l}404 \\
38 \\
11\end{array}$ & $\begin{array}{l}X^{2}=3.017 \\
D f=2 \\
P=0.227\end{array}$ \\
\hline $\begin{array}{l}\text { Level of } \\
\text { education } \\
\text { None or primary } \\
\text { Secondary/ more }\end{array}$ & $\begin{array}{l}0(0.0) \\
15(3.5)\end{array}$ & $\begin{array}{l}24(100.0) \\
414(96.5)\end{array}$ & $\begin{array}{l}24 \\
429\end{array}$ & $\begin{array}{l}\mathrm{X}^{2}=0.868 \\
\mathrm{Df}=1 \\
\mathrm{P}=1.000\end{array}$ \\
\hline $\begin{array}{l}\text { Occupation } \\
\text { Unemployed } \\
\text { Unskilled } \\
\text { Semiskilled } \\
\text { Skilled/technical } \\
\text { Professional }\end{array}$ & $\begin{array}{l}2(1.4) \\
6(5.3) \\
2(3.6) \\
4(3.1) \\
1(6.7)\end{array}$ & $\begin{array}{l}139(98.6) \\
108(94.7) \\
54(96.4) \\
123(96.9) \\
14(93.3)\end{array}$ & $\begin{array}{l}141 \\
114 \\
56 \\
127 \\
15\end{array}$ & $\begin{array}{l}X^{2}=3.484 \\
D f=4 \\
P=0.321\end{array}$ \\
\hline
\end{tabular}

Table 4: Reasons mothers refuse caesarean section and number of children preferred by them

\begin{tabular}{|l|l|l|}
\hline Reasons for preferences & Pumber (n) & \\
\hline $\begin{array}{l}\text { Reasons mothers refuse c-section even } \\
\text { though it is the only safe option for } \\
\text { delivery }\end{array}$ & & \\
It's against God's plan for procreation & 59 & 66.3 \\
It's a sign of failure of womanhood & 15 & 16.8 \\
It has a higher risk of death & 7 & 7.9 \\
It limits number of children one could have & 4 & 4.5 \\
Other reasons & 4 & 4.5 \\
\hline Total & 89 & 100.0 \\
\hline Would you rather allow your baby to die & & \\
than accept c-section? & 10 & \\
Yes & 428 & 2.3 \\
No & 438 & 97.7 \\
\hline Total & & 100.0 \\
\hline Number of children mothers prefer to have & \\
1 & 0 & \\
2 & 8 & 0.0 \\
3 & 104 & 1.7 \\
4 & 249 & 23.0 \\
5 & 50 & 55.0 \\
$>6$ & 42 & 11.0 \\
& 453 & 9.3 \\
\hline Total & & 100.0 \\
\hline Reasons for number of children preferred & \\
by mothers & 259 & \\
I prefer a small family of 4 or less & 65 & 57.2 \\
To consolidate my marriage & 14.4 \\
\hline
\end{tabular}


Motherhood Choices of women Attending Antenatal Care in A Tertiary Level....

\begin{tabular}{|l|l|l|}
\hline To reduce cost of running the family & 55 & 12.1 \\
To satisfy my husband & 35 & 7.7 \\
I prefer a larger family of 5 or more & 39 & 8.6 \\
\hline Total & $\mathbf{4 5 3}$ & $\mathbf{1 0 0 . 0}$ \\
\hline
\end{tabular}

Table 5: Association between selected respondents' parameters and refusal to accept caesarean section as the only safe option for delivery.

\begin{tabular}{|c|c|c|c|c|}
\hline \multirow[t]{2}{*}{ Parameters } & \multicolumn{2}{|c|}{$\begin{array}{l}\text { Acceptance of c-section if } \\
\text { that is the only safe delivery } \\
\text { option available }\end{array}$} & \multirow[t]{2}{*}{ Total } & \multirow[t]{2}{*}{$\begin{array}{l}\text { Statistical tests } \\
\text { and values }\end{array}$} \\
\hline & Yes n $(\%)$ & No n $(\%)$ & & \\
\hline $\begin{array}{l}\text { Age Group } \\
<30 \\
>30\end{array}$ & $\begin{array}{l}228(77.0) \\
136(86.6)\end{array}$ & $\begin{array}{l}68(23.0) \\
21(13.4)\end{array}$ & $\begin{array}{l}296 \\
157\end{array}$ & $\begin{array}{l}X 2=5.985 \\
D f=1 \\
P=0.546\end{array}$ \\
\hline $\begin{array}{l}\text { GA groups } \\
<37 \mathrm{wks} \\
>37 \mathrm{wks}\end{array}$ & $\begin{array}{l}348(80.0) \\
16(88.9)\end{array}$ & $\begin{array}{l}87(20.0) \\
2(11.1)\end{array}$ & $\begin{array}{l}435 \\
18\end{array}$ & $\begin{array}{l}X 2=0.865 \\
D f=1 \\
P=1.000\end{array}$ \\
\hline $\begin{array}{l}\text { Parity } \\
0-4 \\
>5\end{array}$ & $\begin{array}{l}358(80.6) \\
6(66.7)\end{array}$ & $\begin{array}{l}86(19.4) \\
3(33.3)\end{array}$ & $\begin{array}{l}444 \\
9\end{array}$ & $\begin{array}{l}X 2=1.090 \\
D f=1 \\
P=0.388\end{array}$ \\
\hline $\begin{array}{l}\text { Booking Status } \\
\text { Booked } \\
\text { Unbooked } \\
\text { Referred }\end{array}$ & $\begin{array}{l}324(80.2) \\
31(81.6) \\
9(81.8)\end{array}$ & $\begin{array}{l}80(19.8) \\
7(18.4) \\
2(18.2)\end{array}$ & $\begin{array}{l}404 \\
38 \\
11\end{array}$ & $\begin{array}{l}X 2=0.057 \\
D f=2 \\
P=1.000\end{array}$ \\
\hline $\begin{array}{l}\text { Tribe } \\
\text { Akwa Ibom indigenes } \\
\text { Non indigenes }\end{array}$ & $\begin{array}{l}288(79.3) \\
76(84.4)\end{array}$ & $\begin{array}{l}75(20.7) \\
14(15.6)\end{array}$ & $\begin{array}{l}363 \\
90\end{array}$ & $\begin{array}{l}X 2=1.191 \\
D f=1 \\
P=0.303\end{array}$ \\
\hline $\begin{array}{l}\text { Level of education } \\
\text { None or primary } \\
\text { Secondary/higher }\end{array}$ & $\begin{array}{l}15(62.5) \\
349(81.4)\end{array}$ & $\begin{array}{l}9(37.5) \\
80(18.6)\end{array}$ & $\begin{array}{l}24 \\
429 \\
\end{array}$ & $\begin{array}{l}X 2=5.117 \\
D f=1 \\
P=0.033\end{array}$ \\
\hline $\begin{array}{l}\text { Occupation } \\
\text { Unemployed } \\
\text { Unskilled } \\
\text { Semiskilled } \\
\text { Skilled/technical } \\
\text { Professional }\end{array}$ & $\begin{array}{l}106(75.2) \\
86(75.4) \\
41(73.2) \\
117(92.1) \\
14(93.3)\end{array}$ & $\begin{array}{l}35(24.8) \\
28(24.6) \\
15(26.8) \\
10(7.9) \\
1(6.7)\end{array}$ & $\begin{array}{l}141 \\
114 \\
56 \\
127 \\
15\end{array}$ & $\begin{array}{l}X 2=18.695 \\
D f=4 \\
P=0.000\end{array}$ \\
\hline
\end{tabular}

